\title{
High Sensitive Tilt Sensor for Quartz Micromachining
}

\author{
Fusao Kohsaka Student Member (Waseda University, f-kousaka@fuji.waseda.jp) \\ Jinxing Liang Member (Sakamoto Electric Mfg., liang@kyushu.rise.waseda.ac.jp) \\ Takahiro Matsuo Student Member (Waseda University, t.matsuo@ruri.waseda.jp) \\ Toshitsugu Ueda Member (Waseda University, t-ueda@waseda.jp)
}

Keywords : quartz, tilt sensor, capacitance, micromachining, anisotropic etching

Many kinds of tilt sensors have been developed and applied to the field of tilt angle measurement. However, the improvement of "Size", "Cost", "Operability" and other "Performances" is expected. We examined the possibility of development of tilt sensor fabricated by quartz crystal anisotropic-etching technology which is suitable for mass production.

Fig. 1 shows the quartz tilt sensor which is constructed of "Beam spring", "Moving element" and "Capacitive detector of comb electrode". The principle of sensor is that the displacement of moving element caused by tilt angle is detected as capacitance change of comb electrode. Two sets of comb electrodes in moving element constitute the differential detection system for high accuracy and high stability.

We analyzed the performance of the sensor chip with a size of $5 \times 5 \times 0.1 \mathrm{~mm}^{3}$. The result of analysis showed that the performance of sensor is realizable with the high aspect ratio of spring and comb electrode. We evaluated the wet etching property of our laboratory fabrication process, in order to check the possibility of a high aspect ratio. Quartz wafer is etched by $\mathrm{NH}_{4} \mathrm{HF}_{2}$ solution, and Fig. 2 shows SEM photograph of etched device.

Cross section photograph of beam spring shows the high aspect

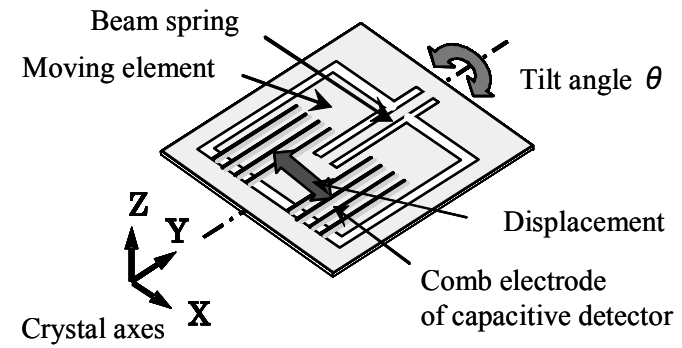

Fig. 1. Basic construction

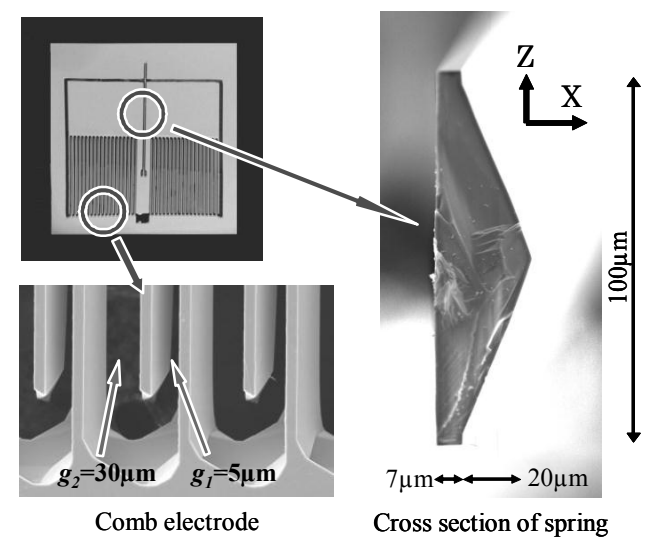

Fig. 2. SEM photograph of etched device ratio which etched the pattern width $7 \mu \mathrm{m}$ with wafer thickness $100 \mu \mathrm{m}$. The gap of comb element is fabricated to the design value $g_{1}=5 \mu \mathrm{m}$, and $g_{2}=30 \mu \mathrm{m}\left(>g_{1}\right)$ contributes to the fabrication process of electrode patterns.

After removing all thin films from the etched wafer, the thin films are sputtered on all of wafer surface including side wall of comb element. After the thin film sputtering, we formed the electrode patterns of comb element by Lift-Off method. The photograph of sensor chip with electrode, and the mounted sensor chip in the ceramic package are shown in Fig. 3.

We evaluated the packaged sensor with electronic circuit. The electronic circuit is capacitance - voltage converter designed for this sensor. Two sets of comb electrodes are connected to the diode bridge circuit of electronic circuit, and electronic circuit outputs the differential signal proportional to the tilt angle.

We built the computer controlled equipment for sensor evaluation, and the equipment is set on the ceramic bed in temperature controlled room. Fig. 4 shows the example of measured data that is the sensor output voltage by the incrementation of tilt angle 0.002 degree step. We checked that the sensor has 0.0001 degree resolution by the statistical analysis of measured data.

We developed high resolution tilt sensor using quartz crystal anisotropic-etching technology. The feature of this sensor is that sensor chip is arranged horizontally. This means that "Two axes sensor" will be able to fabricate on one wafer chip.

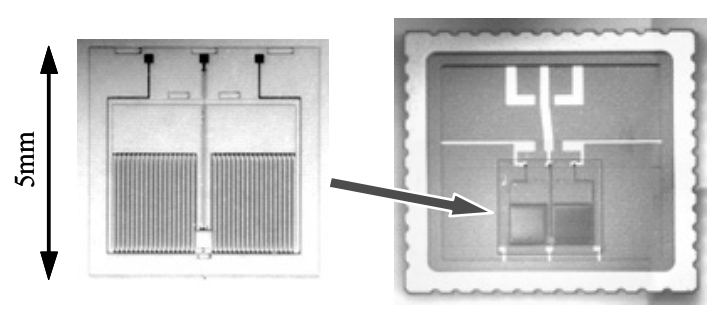

Fig. 3. Sensor chip and packaged sensor

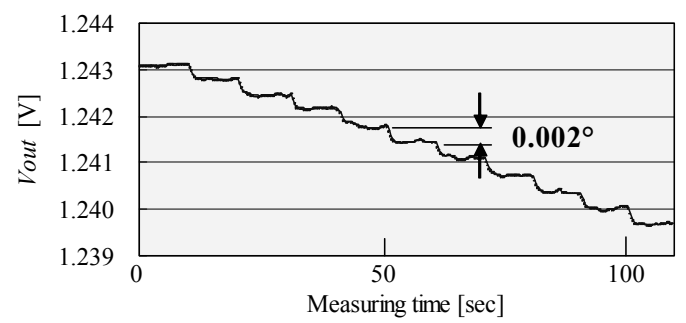

Fig. 4. Input angle 0.002 degree step 


\title{
水晶マイクロ加工による高感度傾斜角センサ
}

\author{
学生員 幸坂扶佐夫* 正 員 梁 金星** \\ 学生員 松尾 高博* 正 員 植田 敏嗣*
}

\author{
High Sensitive Tilt Sensor for Quartz Micromachining \\ Fusao Kohsaka*, Student Member, Jinxing Liang**, Member, \\ Takahiro Matsuo*, Student Member, Toshitsugu Ueda*, Member
}

Many kinds of tilt sensors have been developed and applied to the field of tilt angle measurement. However, the improvement of a "Size", "Cost", "Operability" and other "Performances" is expected. On the other hand, the high performance acceleration sensors were developed by MEMS technology, but there is almost no high sensitive MEMS sensor that detects a minute gravity change. We examined the possibility of development of tilt sensor fabricated by quartz crystal anisotropic-etching technology which is suitable for mass production.

The developed tilt sensor is constructed of "Beam spring", "Moving element" and "Capacitive detector of comb electrode". The feature of this sensor is that sensor chip is placed horizontally, and this arrangement enables fabrication of "Two axes sensor" on one wafer chip. We developed quartz tilt sensor using our laboratory fabrication process. Size of sensor chip is $5 \times 5 \times 0.1 \mathrm{~mm}^{3}$, and the evaluation result showed the highest level performance of 0.0001 degree resolution.

キーワード : 水晶, 傾斜角センサ, 静電容量, マイクロ加工, 異方性エッチング

Keywords : quartz, tilt sensor, capacitance, micromachining, anisotropic etching

\section{1. はじめに}

傾斜角測定は水準器に代表されるように土木や建築をは じめとするいろいろな分野で利用されている。また近年に おいては，工場における製造装置の高精度化にともなう水 平度の高精度測定の要求や, さらにはセンサの小型化が実 現すれば種々のハンディ機器への搭載も期待されていると ころである。

このような傾斜角測定の分野においては，微少な角度を 測定するために差動方式やサーボ方式など様々な検出方法 をもとに各種センサが考案され, 分解能 $0.0001^{\circ}$ という高感 度のセンサも実用に供されている。しかし，大きさ，コス 卜，使いやすさ等の高性能化への要求が大きいにも拘わら ず，それらの期待に応えられるセンサに乏しいのも事実で ある。

小型高性能化の要求に応える技術として MEMS 技術が発

* 早稲田大学大学院情報生産システム研究科

干808-0135 福岡県北九州市若松区ひびきの 2-7

WASEDA UNIVERSITY The Graduate School of Information, Production and Systems

2-7 Hibikino, Wakamatsu-ku, Kitakyushu, Fukuoka 808-0135

** (株)坂本電機製作所

T 811-0202 福岡県福岡市東区和白 3-27-55

Sakamoto Electric MFG.Co.LTD

3-27-55 Wajiro, Higashi-ku, Fukuoka 811-0202
展してきており, その中でも加速度センサへの応用例 ${ }^{(1)}$ は多 いが，微少重力変化を検出する傾斜角センサの開発例は少 ない。我々は, 水晶の異方性エッチング特性, とくにウェ ットエッチングによる高アスペクト比加工が可能な特長を 利用した傾斜角センサの開発について検討を行った(2)(3)。そ の結果, 傾斜角 $0.0001^{\circ}$ クラスの分解能を有する高感度傾斜 角センサが実現可能であることを確認した。

ここでは, 傾斜角測定器の重要な構成要素となる傾斜角 センサの基本構成と特性解析結果, また試作評価したセン サデバイスの製作プロセスおよび評価結果について報告す る。

\section{2. 基本構成}

量産性に優れたウェットエッチング加工と, 水晶の異方 性エッチングの特長を生かした基本構成を検討した。図 1 のように, センサは一枚の水晶ウェハからエッチングによ り加工され, バネと質量 $M$ の可動部, また傾斜角入力によ る微少変位を静電容量変化として検出する櫛形電極部で構 成される。水平に配置されたセンサの $\mathrm{Y}$ 軸回りに $\theta$ の傾斜 角が入力されると, 可動部には $M g \cdot \sin \theta$ の力が作用し, こ れによりバネが $\Delta x$ だけ変位する。この変位を可動部に形成 してある櫛形電極部で静電容量変化として検出する。この 


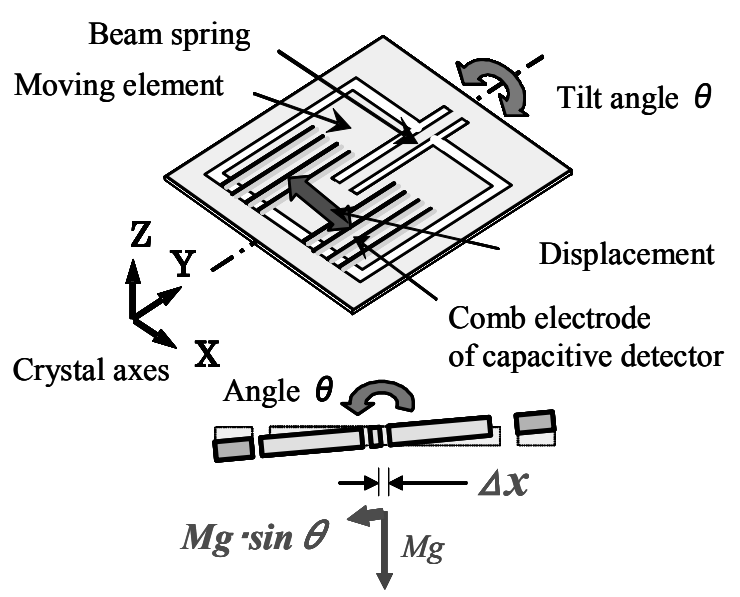

Fig. 1. Basic Construction

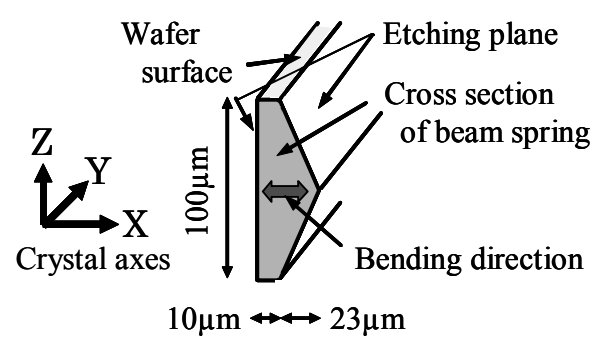

Fig. 2. Shape of beam spring

ように，傾斜角入力を水晶ウェ八の平面内変位として検出 することで，1 チップに X-Y 二軸のセンサを構成できるの が大きな特長である。

小型高感度化のためにはバネの剛性を極力小さく設計す る必要がある。水晶の単結晶ウェハはフッ酸系の溶液に対 して大きなエッチング異方性を示す(4)。とくに，図 2 の結晶 方位と $\mathrm{NH}_{4} \mathrm{HF}_{2}$ 溶液によるウェットエッチングにより非常 に高いアスペクト比のバネ加工が可能となる。

静電容量検出部には差動検出方式を採用し ${ }^{(5)}, \mathrm{X}$ 軸回りの 傾斜入力の影響や外乱に対して安定なセンサを実現する。 また，櫛形電極部の電極構成について検討し，微細櫛歯部 での電極分離が不要な構成を実現した。この構成は，セン サ設計において工夫を要するが，製造プロセスにおいて多 大なメリットをもたらすものである。

\section{3. 特性解析}

〈3·1〉 バネの剛性 傾斜角 $\theta$ が入力したときにバネ の先端に生じるたわみ角 $\phi$ と変位 $\Delta x$ は, 可動部質量の荷重 $W=M g \sin \theta$ によりバネに生じるモーメントをバネ全長 $L$ に わたって積分することで得られる。

バネ先端のたわみ角 $\phi$ は, 荷重 $W$ によるモメント $M w$ と可動部重心がバネ先端から Lo 離れていることで生じるモ 一メント $M c$ の和を積分することで(1)式のように求められ る。同様に，(1)式のバネたわみ角 $\phi(x)$ を積分することでバ ネ先端の変位 $\Delta x$ は $(2)$ 式となる。

$$
\phi=\int_{0}^{L} \frac{M w(x)+M c}{E I} d x=\frac{W L^{2}}{2 E I}\left(1+2 \frac{L o}{L}\right)
$$

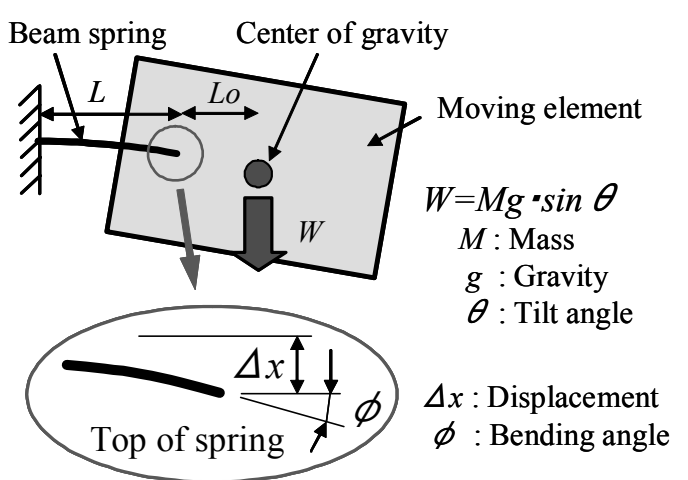

Fig. 3. Bending of beam spring

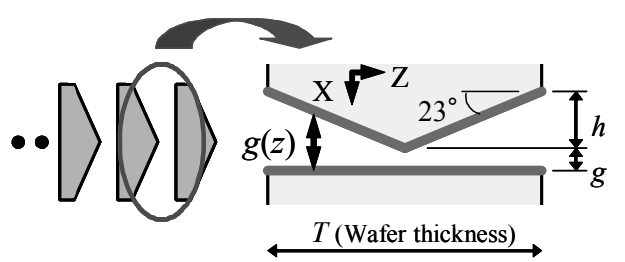

Fig. 4. Cross section of comb electrode

$$
\Delta x=\int_{0}^{L} \phi(x) d x=\frac{W L^{3}}{3 E I}\left(1+\frac{3 L o}{2 L}\right)
$$

ここで， $E$ はヤング率 (水晶の $1 / S_{22}$ )，I はバネの断面二 次モーメントである。

これらのたわみ角 $\phi$ と変位 $\Delta x$ を用いて櫛形電極部の静 電容量の変化量を求めることができる。

\section{$\langle 3 \cdot 2\rangle \quad$ 電極部の静電容量}

(1) 電極間静電容量 静電容量を構成する櫛形電極 部の断面は異方性エッチング特性により図 2 と同様に図 4 のような形状に加工される。この断面の角度はミラー指数 [2-1-11](24.4)であるが, 試作サンプルの電子顕微鏡観察に よると, この傾斜は直線ではなく平均角度としては $23^{\circ}$ を採 用するのが妥当と結論づけられる。これは，[2-1-11]面が 形成された後に，不要な結晶面がなくなるまでエッチング を継続することにより，[4-2-21](12.8 $)$ と推定される結晶面 のエッチングが進行するためと考えられる。

このような形状の電極間静電容量は，電極間隔を $\mathrm{Z}$ 方向 の関数 $g(z)=(2 h / T) z+g$ と表記し積分することで得られる。

$$
C=2 \int_{0}^{T / 2} \frac{\varepsilon H}{g(z)} d z=\frac{\varepsilon T H}{h} \ln \left(\frac{g+h}{g}\right)
$$

ここで， $\varepsilon$ は電極間媒体の誘電率， $H$ は $\mathrm{Y}$ 軸方向の電極 長， $T, g, h$ は図中の寸法である。

一方で, この静電容量を形成する電極は $(1)$ 式で求められ るように電極長さ方向に $\phi$ だけ傾斜する。したがって，(3) 式の $g$ を長さ方向 $\mathrm{Y}$ の関数 $g(y)$ として電極全長にわたって 積分する必要がある。その結果, 一組の対向電極で構成さ れる静電容量は(4)式のように表される。

$$
C=\frac{\varepsilon T}{h} \int_{0}^{H} \ln \left(\frac{g(y)+h}{g(y)}\right) d y
$$




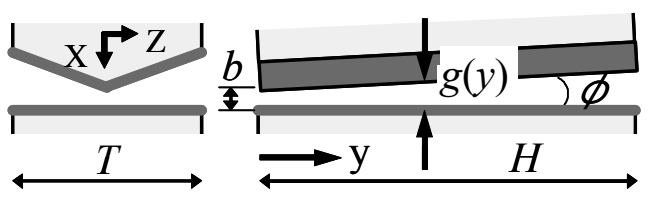

Fig. 5. Slope of electrode

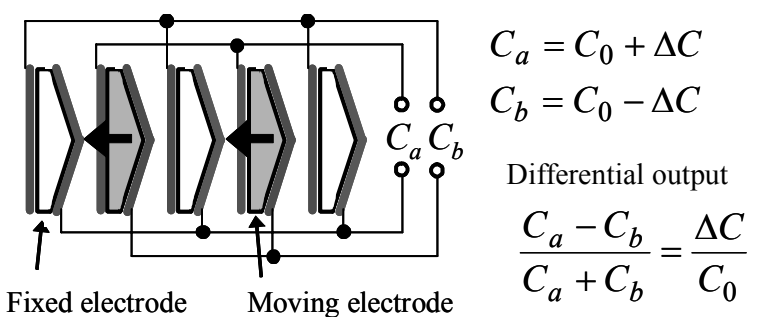

Fig. 6. Basic system for differential output

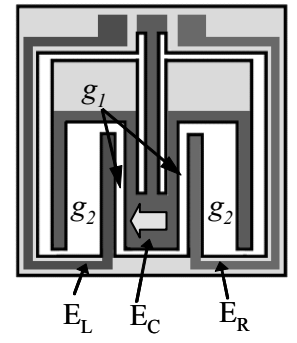

$\mathrm{E}_{\mathrm{L}}$ : Left fixed electrode $\mathrm{E}_{\mathrm{R}}:$ Right fixed electrode $\mathrm{E}_{\mathrm{C}}$ : Common electrode of moving element

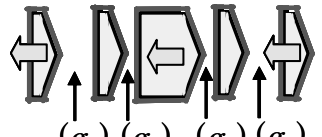

$\left(g_{2}\right)\left(g_{1}\right) \quad\left(g_{1}\right)\left(g_{2}\right)$ $C_{2 L} C_{1 L} \quad C_{1 R} C_{2 R}$
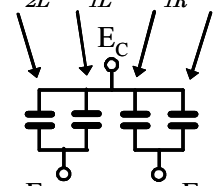

$\mathrm{E}_{\mathrm{L}}$ $C_{I L}=C_{I R}=C_{I}$ at $\theta=0^{\circ}$ $C_{2 L}=C_{2 R}=C_{2}$ at $\theta=0^{\circ}$
Fig. 7. Electrode for differential detection with $g_{1}, g_{2}$

ここで, $g(y)=a y+b, g(y)+h=a y+c(a=\tan \phi)$ とおくことで ( 5 )式の解析解を得ることができる。

$$
C=\frac{\varepsilon T}{h} \frac{1}{a}[(a y+c) \ln (a y+c)-(a y+b) \ln (a y+b)]_{0}^{H}
$$

（2）櫛形電極部の電極構成センサデバイスを製作 する上で節形電極部の電極分離形成プロセスが大きな問題 となる。さらに，外乱に対して微小信号を安定に検出する ために差動方式を採用するため，この差動構成が電極分離 を困難にしている。水晶エッチング後に電極用薄膜をスパ ッタし，図 6 のような微細楖歯表面部（幅 $10 \mu \mathrm{m} ）$ で電極を 分離加工するのは製造プロセス上大きな負担となる。

本センサではこの問題を解決するために図 7 の電極構成 を考案し特性について検討した。簡単のために櫛形電極は 一対のみの構成で示している。

櫛歯表面部では電極分離せずに，櫛歯表面全てが薄膜電 極で覆われている状態である。固定電極全体をデバイス中 心線部で左右に二分割し, 可動電極は分割しない共通電極 とする構成であるため, 図 6 のように楖歯部での電極分離 が不要で電極形成が非常に容易になる。一対の櫛形電極で 構成される静電容量はギャップ $g_{1}$ と $g_{2}$ で形成される静電容 量 $C_{1}$ と $C_{2}$ の和となる。

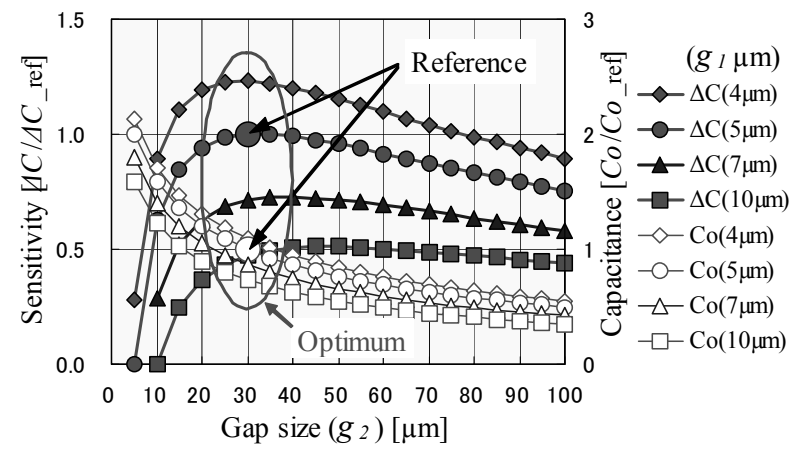

Fig. 8. Sensitivity and capacitance by $g_{1}, g_{2}$
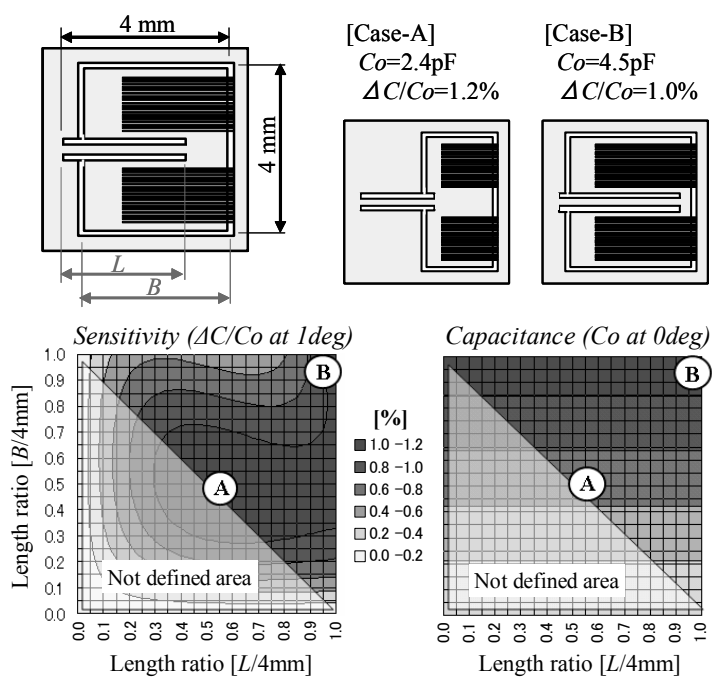

Capacitance (Co at Odeg)
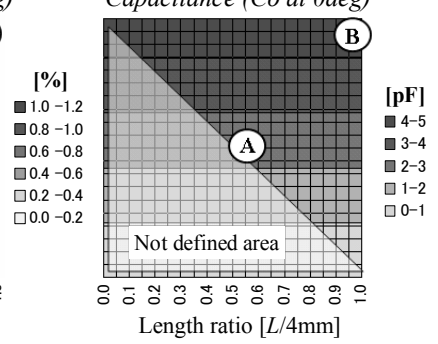

Fig. 9. Analytical model and calculated result

この構成において, 傾斜角入力により可動部が矢印方向 に微小変位すると各々の静電容量変化から差動信号は( 6 ) 式となる。電極形成が容易となる反面, $g_{2}$ の静電容量変化 $\Delta C_{2}$ が信号成分 $\Delta C_{1}$ を打ち消寸方向に作用するため $g_{1}$ と $g_{2}$ の組み合わせが最適となる条件を見出す必要がある。

$$
\begin{aligned}
& C_{1 L}=C_{1}+\Delta C_{1}, C_{2 L}=C_{2}-\Delta C_{2} \\
& \rightarrow C_{L}=C_{1 L}+C_{2 L}=\left(C_{1}+C_{2}\right)+\left(\Delta C_{1}-\Delta C_{2}\right) \\
& C_{1 R}=C_{1}-\Delta C_{1}, C_{2 R}=C_{2}+\Delta C_{2} \\
& \rightarrow C_{R}=C_{1 R}+C_{2 R}=\left(C_{1}+C_{2}\right)-\left(\Delta C_{1}-\Delta C_{2}\right) \\
& \therefore \frac{C_{L}-C_{R}}{C_{L}+C_{R}}=\frac{\Delta C_{1}-\Delta C_{2}}{C_{1}+C_{2}}
\end{aligned}
$$

図 8 は $5 \times 5 \times 0.1 \mathrm{~mm}^{3}$ のデバイス寸法において, $g_{1}$ と $g_{2}$ の值を変化させた場合の傾斜角感度と初期容量の計算結果 である。 $g_{1}$ をパラメータに $g_{1}=5 \mu \mathrm{m}, g_{2}=30 \mu \mathrm{m}$ の場合を基準 として相対表示したものである。 $g_{2}$ が小さい領域では( 6 ) 式のように $\Delta C_{2}$ が大きいため感度が小さく, $g_{2}$ が大きくな ると可動部質量が低下することにより感度が小さくなる。 結果として, 設計上実用的な $g_{1}=5 \mu \mathrm{m}$ 前後においては $g_{2}=30 \mu \mathrm{m}$ 付近において感度が最大になり, かつ初期容量の 低下も比較的小さな最適領域が存在することがわかる。 
（3） センサの特性 以上の（1)〜（6)式をもとに具体 的な特性について検討した。初期容量 $C_{0}=C_{1}+C_{2}=3 \mathrm{pF}$, 感度 (傾斜角 $1^{\circ}$ における容量変化率) $\Delta C / C_{0}=1 \%$ を目標值とし, 5 $\times 5 \times 0.1 \mathrm{~mm}^{3}$ のデバイス外形寸法, $g_{1}=5 \mu \mathrm{m}, g_{2}=30 \mu \mathrm{m}$ の条 件で実現性を解析検討した。

図 9 はバネ長 $L$ と可動部長 $B$ をパラメータに初期容量と 傾斜角感度を数值計算した結果である。グラフの左下は $(L+B)<4 \mathrm{~mm}$ のために実現不可能な領域であり, 形状例とし て A と B 点を Case-A，B に示した。感度のグラフから，バ ネ長や可動部長だけではなく可動部の重心位置の影響も大 きいことが理解できる。いずれにしても，十分に目標をク リアできる特性が得られることがわかった。

\section{4. センサ試作}

水晶は圧電特性以外にいろいろな優れた特性を有してい る。ここでは, 弾性特性, エッチング異方性, 電気絶縁性 などの諸特性とフォトリソグラフィ技術を用いてセンサを 試作する。製造プロセスはセンサの形状エッチング加工と 静電容量電極用パターン形成に大きく分けられる。

〈4·1〉形状エッチング 図 10 に示すように, 露光用 のマスク作成から始まり，1)の薄膜スパッタから 5)の水晶エ ッチングまで研究室の試作プロセスで自作した。

スパッタから水晶エッチングまで，全て両面同時処理が基 本となるため, ウェハの扱いや表裏のパターンのアライメ ントなどに細心の注意が要求される。水晶のエッチングに は $\mathrm{NH}_{4} \mathrm{HF}_{2}$ 溶液を使用し, ウェットエッチングにより高アス ペクト比のバネおよび電極を加工する。

エッチング加工後のセンサ各部の SEM 写真を図 11 に示 す。バネや電極各部の断面写真から, 期待した高アスペク ト比の微細加工が実現できていることがわかる。

〈4·2〉 静電容量電極形成 形状エッチング加工とと もに静電容量構成のための電極形成フォトリソは重要な工 程である。エッチング加工後の凹凸が存在するウェハ八の

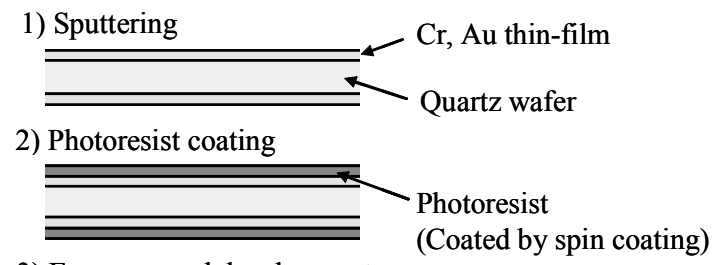

3) Exposure and development (Coated by spin coating)
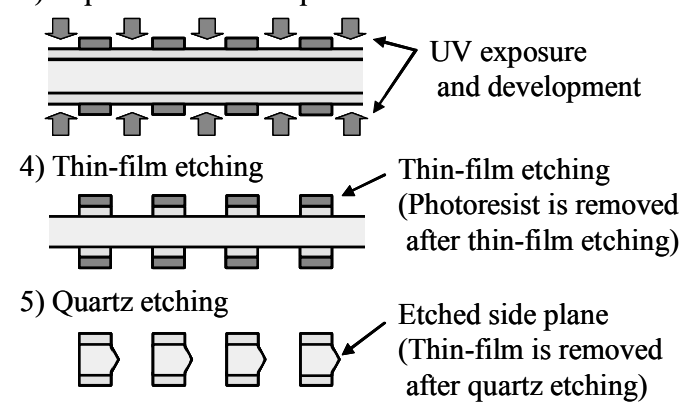

Fig. 10. Fabrication process for quartz etching

レジスト塗布方法としてスプレーコート法の報告例がある が，我々はリフトオフ法を適用して電極形成を試みた。

検討したリフトオフ法は図 12 のプロセスで実現した。

(1) 図 10-4)のプロセスの後, 電極分離のためのレジス トパターンを形成する。

（2）水晶をセンサ形状にエッチング加工した後, 薄膜を エッチングで除去する。

(3) $\mathrm{Cr}, \mathrm{Au}, \mathrm{Cr}$ の 3 層薄膜をスパッタする。これによ り電極部側面にも薄膜が形成される。その後, 溶剤でレジ ストを除去することで，レジスト上の薄膜がリフトオフさ

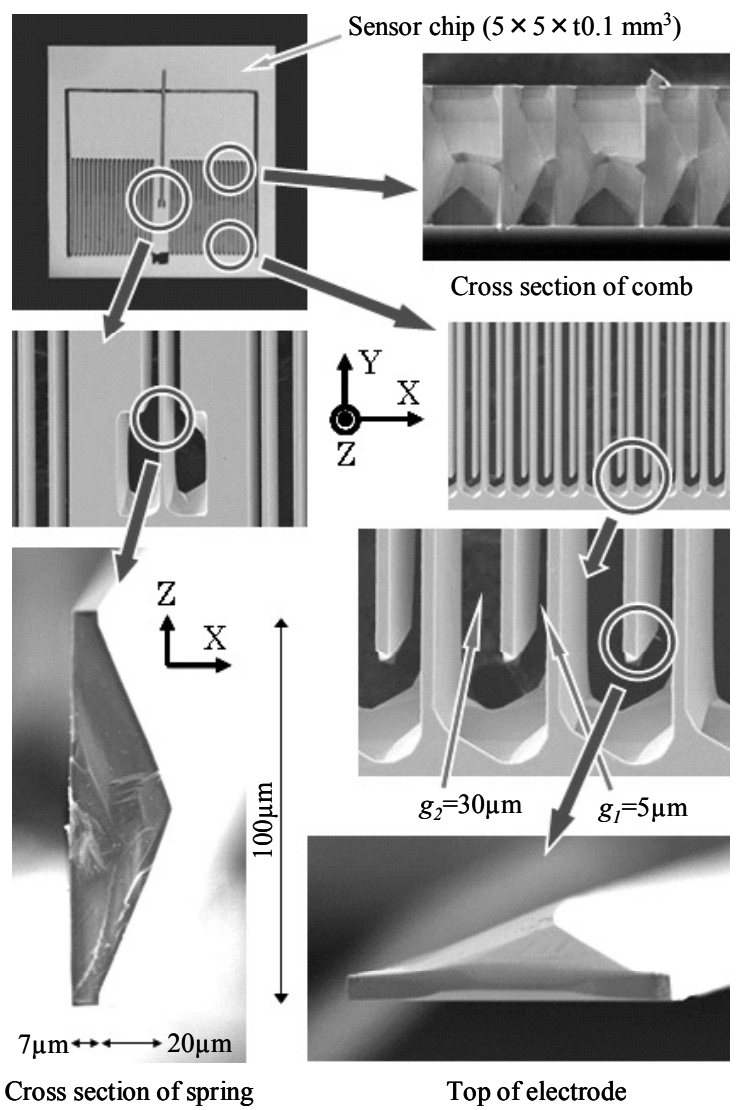

Fig. 11. SEM photographs of fabricated sensor

1) Resist pattern on thin-film

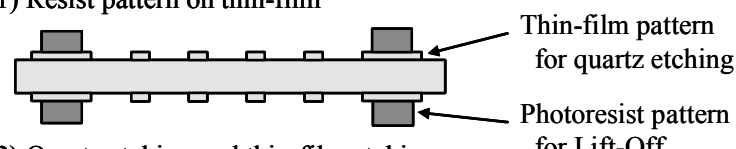

2) Quartz etching and thin-film etching

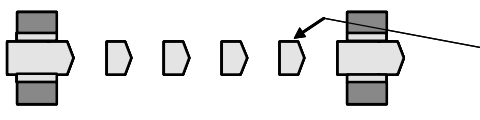

3) Spattering and Lift-Off 500010

4) Thin-film etching $\square \square \square \square \square$

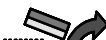
after quartz etching

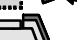

Thin-film is lifted off by Lift-Off method

Fig. 12. Fabrication of electrode by Lift-Off method 


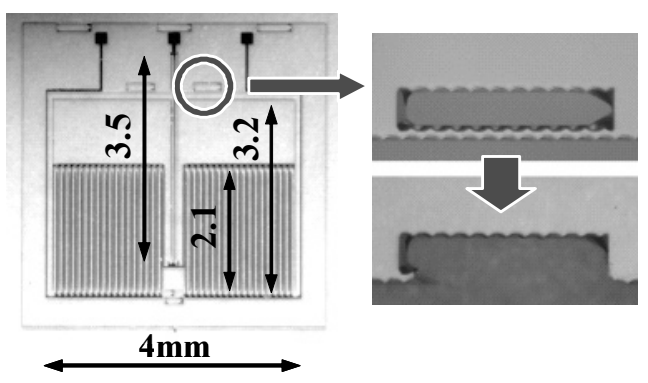

Fig. 13. Sensor device with electrode

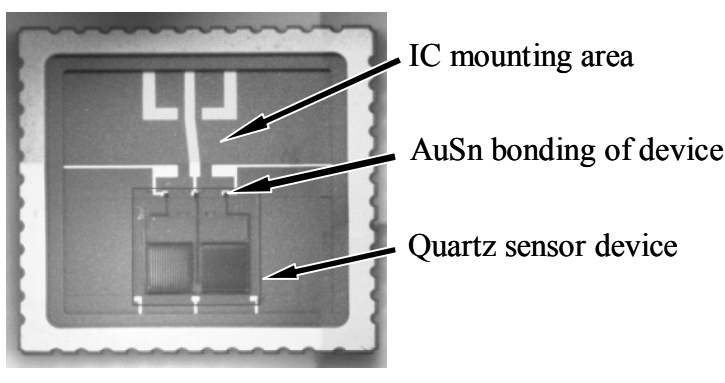

Fig. 14. Packaged sensor device

れる。

(4) $\mathrm{Au}, \mathrm{Cr}$ の順で薄膜をエッチング除去すると電極パ ターンが残り電極配線パターンが形成される。

〈4·3〉 試作結果リフトオフ法により電極パターン が形成されたセンサデバイス写真を図 13 に示す。櫛形電極 部と配線パターン以外はリフトオフにより薄膜が除去され 透明な水晶部分が観察できる。デバイス上部に配線パッド があり, 中央が共通電極用パッド, 左右が $C_{L}, C_{R}$ 用電極パ ツドである。

リフトオフ法により電極が形成されたデバイスは，フレ 一ム部側面に残っている電極用薄膜により $C_{L}$ と $C_{R}$ が共通 電極と短絡状態になっている。そこで，フレーム部に設け てある破断部を図 13 のようにカットすることで $C_{L}$ と $C_{R}$ を 電気的に分離する。

完成したデバイスは評価用にパッケージングする必要が ある。設計したパッケージはセラミック製で，デバイスの 近傍に IC を搭載できるように考慮している。パッケージへ のボンディングには AuSn 共晶合金を用いた。デバイスをボ ンディングしたパッケージの写真を図 14 に示す。

\section{5. 評価結果}

〈5·1〉 センサの基本特性評価 センサの基本特性と しては初期容量值と感度特性が重要となる。表 1 に設計值 と実測值の比較を示す。感度特性評価のために傾斜角入力 時の可動電極部の変位量 $(\Delta x)$ を測定した。

初期容量, 感度特性ともにほぼ設計值に近い值が得られ たことから，設計および試作プロセスが良好に実施された ことが確認できた。

〈5·2〉 評価システムの構成 傾斜角入力によるセン サの静電容量変化を電気信号に変換する電子回路と, 微少
Table 1. Characteristics of quartz sensor device

\begin{tabular}{|c|c|c|c|}
\hline & $C_{L}[\mathrm{pF}]$ & $C_{R}[\mathrm{pF}]$ & $\begin{array}{c}\text { Displacement } \\
{\left[\mu \mathrm{m} \text { at } 1^{\circ}\right]}\end{array}$ \\
\hline Design value & 3.1 & 3.1 & 0.18 \\
\hline Measured data & 3.29 & 3.38 & 0.23 \\
\hline
\end{tabular}

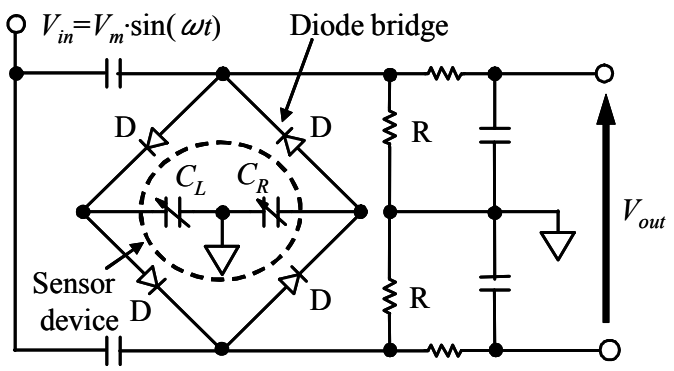

Fig. 15. Electronic circuit for differential detection

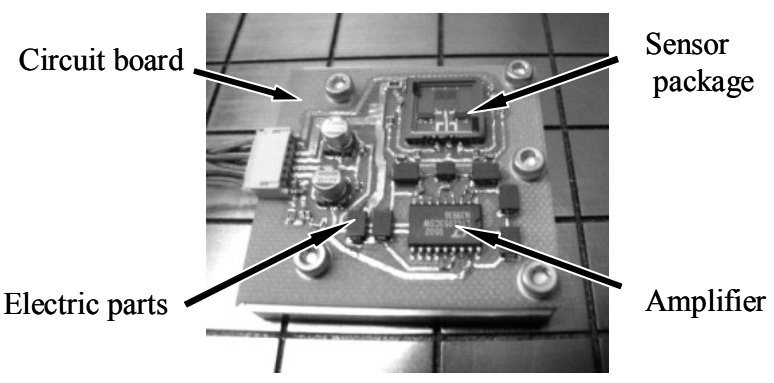

Fig. 16. Sensor unit

傾斜角を発生する装置で評価システムを構成した。

電子回路は差動容量変化を電圧信号に変換するダイオー ドブリッジ方式を用いた。図 15 のダイオードブリッジの両 端にセンサの $C_{L}$ と $C_{R}$ を接続することにより (6)式に比例し た電圧信号 $V_{\text {out }}$ として $(7)$ 式を得ることができる ${ }^{(6)}$ 。

$$
V_{\text {out }}=\frac{2 \cdot\left(V_{m}-V_{f}\right)}{1+\frac{1}{4 f C_{0} R}} \frac{C_{L}-C_{R}}{C_{L}+C_{R}}
$$

ここで， $V_{f}$ はダイオードのフォワード電圧である。

この検出回路の感度は $\Delta C / C_{0}=1 \%$ において $V_{\text {out }}=20 \mathrm{mV}$ で あり，10 倍のアンプおよびセンサデバイスと組み合わせて 傾斜角測定評価用のセンサユニットを製作した。眓 16 に示 すように, 回路基板上に検出回路, アンプ, センサパッケ ージを搭載してある。

微少傾斜角発生装置として図 17 に示すシステムを構築し た。500mm スパンの定盤の片側に微動ステージを取り付け てあり, 最小分解能 $0.0001^{\circ}$ の微少傾斜角を発生できる構成 となっている。

〈5·3〉評価結果 基本動作確認のために傾斜角 $\pm 1^{\circ}$ の範囲において $0.1 \circ$ ステップで角度を変化させたときの出 力電圧を記録した。図 18 の記録データから, 出力電圧感度 は $180 \mathrm{mV} / \mathrm{deg}$ であった。

本センサユニットの測定分解能を評価するために, $0.002^{\circ}$ ステップで角度を変化させた場合のデータを取得した。図 


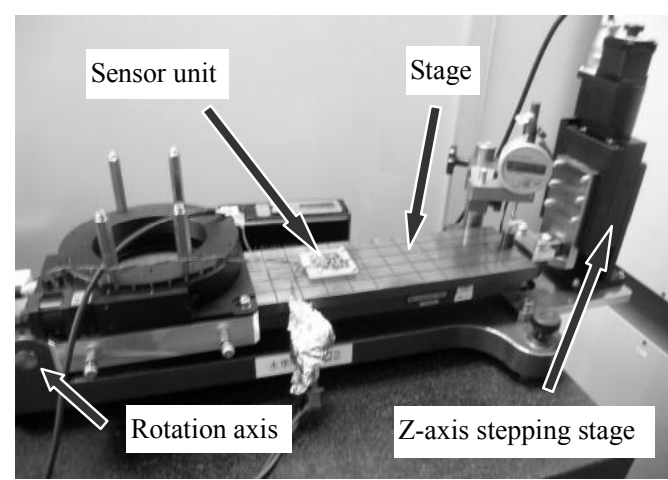

Fig. 17. Evaluation equipment for minute tilt angle

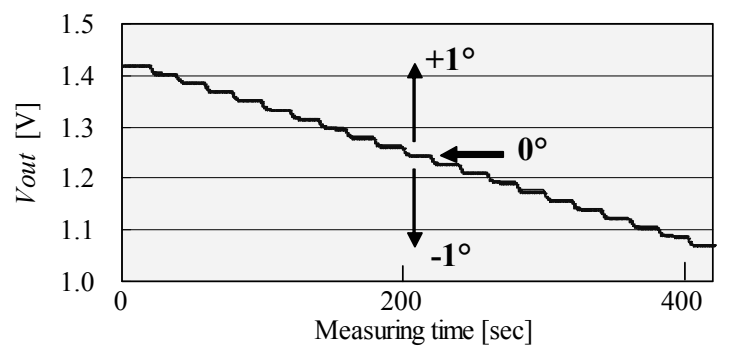

Fig. 18. Input tilt angle \pm 1 degree

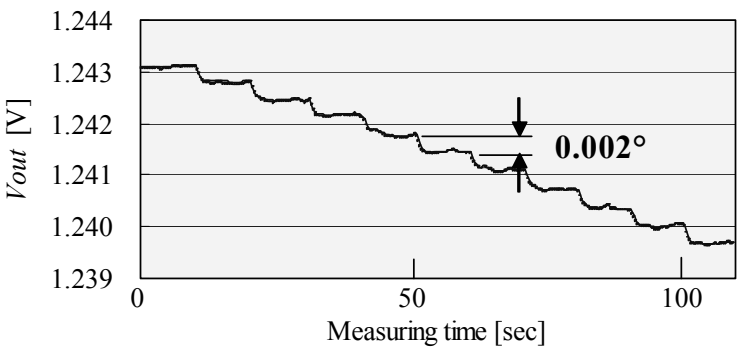

Fig. 19. Input tilt angle 0.002 degree step

19 に結果を示すが, 各角度ステップでのデータの出力安定 度として標準偏差 $\sigma=22 \mu \mathrm{V}$ が得られた。この電圧值 $\sigma$ は傾 斜角換算で約 $0.00013^{\circ} の$ 分解能に相当する值である。

\section{6. むす び}

水晶の異方性エッチングを応用した高感度傾斜角センサ を開発し基本性能を確認した。評価結果から, 最小分解能 $0.0001^{\circ}$ という傾斜角センサとしては最高クラスの性能を有 していることが確認できた。

とくに，量産性に優れたウェットエッチングにより従来 にない高アスペクト比のデバイス加工ができたことは実用 化に向けて大きなステップをクリアしたと考える。

今後は，具体的な傾斜角測定器一の適用化を進めるとと もに，傾斜角測定分野で要求が高い 2 軸傾斜測定用の One-Chip デバイスなどの研究に取り組んでいきたい。

(平成 18 年 10 月 20 日受付，平成 19 年 7 月 3 日再受付)

\section{文献}

(1) K. H. L. Chau, S. R. Lewis, Y. Zhao, R. T. Howe, S. F. Bart, and R. G. Marcheselli : "An integrated force-balanced capacitive accelerometer for low-g application", Sensors and Actuators A 54, pp.472-476 (1996)

（2）幸坂扶佐夫・梁 金星・植田敏嗣:「水晶を用いた高感度傾斜角セン サの検討」，平 17 電学全大講演論文集, p.222 (2005)

( 3 ) F. Kohsaka, J. Liang, and T. Ueda : "High Sensitive Tilt Sensor for Quartz Micromachining", Proceedings of 22nd Sensor Symposium, pp.371-374 (2005)

（4）植田敏嗣・幸坂扶佐夫・飯野俊雄・山崎大輔：「水晶のエッチング形 状の予測法とそのデバイス設計への応用」, 計測自動制御学会論文 集, Vol.23, No.12, pp.1233-1238 (1987)

（5）植田敏嗣- 幸坂扶佐夫・山崎大輔・林 尚典: 「水晶マイクロマシニ ングを利用した高感度マイクロフォン」, 電学論 E, Vol.121，No.12, pp.629-635 (2001)

(6) T. Matsuo, K. Kunitomo, and T. Ueda : "Performance Analysis of a Diode-bridge Type Differential Capacitance Detection Circuit and Its Evaluation", Proceedings of 22nd Sensor Symposium, pp.233-236 (2005)

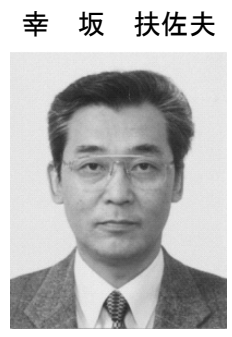

（学生員） 1952 年 9 月 21 日生。1975 年秋田大 学機械工学科卒業, 同年横河電機（株）入社。 変位, 圧力, 温度, 角度などのセンサ開発およ び液晶ディスプレイの製品開発に従事。現在, 早稲田大学大学院博士後期課程。1987 年発明協 会発明奨励賞受賞, 1987 年計測自動制御学会論 文賞受賞。

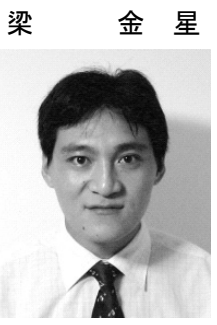

（正員） 1976 年 12 月 13 日生。 2004 年 3 月九 州大学大学院システム情報科学府修了。同年 （株）坂本電機製作所入社, 現在に至る。水晶 を用いたセンサの研究およびデバイス開発に 従事。

松 尾 高 博

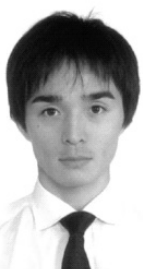

植 田 敏 嗣

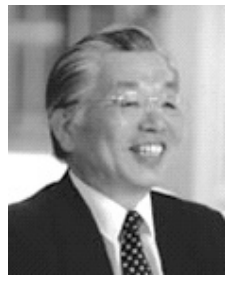

（正員） 1945 年 10 月 4 日生。1971 年 信州大 学大学院修士課程修了, 1988 年東京工業大学工 学博士, 1971 年横河電機 (株) 入社, 2003 年 4 月早稲田大学大学院情報生産システム研究科 教授, 現在に至る。その間, 低雑音増幅器, 機 械振動子，マイクロマシニング，レーザーなど の研究開発とそれを利用した温度, 圧力, 変位, 成分などのセンサ開発に従事。1985 年及び 1987 発明協会より発明奨励賞受賞, 1987 年及び 1994 年計測自動制御学 会より論文賞受賞。計測自動制御学会の会員。 